\title{
DANTE ALIGHIERI COMEMORADO NA UNIVERSIDADE DO PARANÁ
}

Sob a presidência de honra do Magnífico Reitor, Prof. Dr. José Nicolau dos Santos, estudioso da filosofia politica de Dante Alighieri, do Diretor da Faculdade de Filosofia, Prof. Dr. Homero Batista de Barros, e do Cônsul Geral da Itália, Dr. Armando Rota, foi solenemente comemorado na Universidade do Paraná, o sétimo centenário do nascimento de Dante Alighieri.

Os Professôres do Departamento de Letras, com à testa seu Diretor, Prof. Dr. Osvaldo Arns, e os Centros de Estudos de Letras e de História da Faculdade de Filosofia, Ciências e Letras promoveram uma semana de extensāo universitária sōbre Dante, cuja organizaçāo ficou a cargo de uma Comissāo presidida pelo catedrático de Lingua e Literatura Italiana, Prof. Dr. Luigi Castagnola.

De 20 a 24 de setembro de 1965, os Professôres G. D. Leoni, da P.U.C. de São Paulo e da Universidade Mackenzie, Ângelo Ricci, da Universidade do Rio Grande do Sul, e Luigi Castagnola, da Universidade do Paraná, ilustraram aspectos da obra literária do poeta florentino, no anfiteatro da Faculdade de Filosofia, completamente lotado pela assistência.

Os Centros de Estudos de Letras e de História organizaram uma excelente exposição dantesca no hall da Faculdade de Filosofia, com o material gentilmente oferecido pelo Senhor Cónsul da Itália e pelo Centro Cultural Ítalo-Brasileiro Dante Alighieri de Curitiba.

Em mesa redonda, os Professôres Jamile Curi, Reinaldo Bossmann, Miguel Wouk, Heriberto Arns, Otília Arns e Guillermo de la Cruz Coronado apresentaram interessantes relaçōes sôbre Dante e as literaturas modernas. Os alunos dos Cursos de Letras e do Centro Cultural ftalo-Brasileiro declamaram trechos da "Divina Commedia" e da "Vita Nuova".

Na última sessão fizeram ainda uso da palavra o Cônsul Geral da Itália e o Diretor da Faculdade de Filosofia, Prof. Dr. Homero Batista de Barros, que encerrou os festejos comemorativos do sétimo centenário do nascimento de Dante Alighieri.

Os jornais de Curitiba, bem como a TV, noticiaram amplamente as celebrações comemorativas do poeta florentino. 